\title{
Microbiology Specimen Test
}

National Cancer Institute

\section{Source}

National Cancer Institute. Microbiology Specimen Test. NCI Thesaurus. Code C87920.

A character or string that represents a microbiology specimen examination. 